\title{
Design of local roadway infrastructure to service sustainable energy facilities
}

\author{
Karim A AbdelWarith ${ }^{1}$, Panagiotis Ch Anastasopoulos ${ }^{2 *}$, Wayne Richardson ${ }^{3}$, Jon D Fricker ${ }^{1}$ and John E Haddock
}

\begin{abstract}
Background: This paper aims to identify specific local roadway infrastructure design guidelines associated with the construction and operation of sustainable energy source facilities, such as ethanol plants, biomass plants, and wind farm facilities.

Methods: Data associated with sustainable energy facility traffic in Indiana were collected to develop Excel-based tools (worksheets) and assist local agencies in the design of pavements in the proximity of ethanol plants, biomass plants, and wind farms.

Results: To that end, a simple procedure is presented, which provides a design capable of withstanding heavy traffic loads, while, at the same time, quantifies the effects that new sustainable energy source facilities may have on local road networks. The procedure is accompanied by two MS Excel-based software tools that can be used in the design of local roads adjacent to such sustainable energy facilities.

Conclusions: The developed worksheets can serve as a hands-on tool to assist local government engineers in evaluating and in quantifying the probable effects of the construction and operation of a sustainable energy facility in their jurisdiction.
\end{abstract}

Keywords: Sustainable energy facilities; Ethanol plant; Biomass plant; Wind farm; Roadway infrastructure

\section{Background}

Renewable, sustainable energy sources are being developed at a record pace throughout the USA and globally, with multidimensional benefits, as they have the potential to boost local economies and generate new jobs [1-20]. In Indiana, energy corporations have invested in three main types of sustainable energy sources, namely, ethanol, wind, and biomass energy, and have built numerous wind farms and ethanol and biomass plants. It is expected that the number of plants and wind farms will triple by 2022 [21]. Increased loads, increased traffic, or both can negatively affect road networks (with respect to the existing infrastructures, the environment, the aesthetics of the local communities, and the safety of the neighboring residents) when sustainable energy projects are introduced into a community [22-28]. Wind farm construction increases the loads on roads leading to and

\footnotetext{
* Correspondence: panastas@buffalo.edu

${ }^{2}$ Department of Civil, Structural and Environmental Engineering, Institute for Sustainable Transportation and Logistics, University at Buffalo, The State University of New York, 241 Ketter Hall, Buffalo, NY 14260, USA Full list of author information is available at the end of the article
}

from the wind farm during turbine construction, but once the turbines have been constructed, there is nearly no increase in traffic $[26,27]$. Conversely, when a fixedpoint energy source that must be serviced by trucks is constructed, such as an ethanol or biomass plant, it results in additional traffic, and on many occasions, increased loads [22-25]. While it may be possible to mitigate these effects by the use of barge or rail [29], at some point, the road network will need to be used to move the turbine components, or the biomass or ethanol products.

In Indiana, ethanol plants, biomass power plants, and wind farms are typically built in rural areas. Most local road networks were not designed or constructed to accommodate the increased traffic and loads produced by such facilities. When sustainable energy developers decide to locate facilities within a given governmental entity, local officials need to have a sound understanding of the proposed facilities' probable effects on their local road network and some methods to quantify those effects. The local highway engineers and supervisors also 
need to be familiar with the resulting traffic and load problems associated with these facilities and be in a position to make decisions as to which pavement structure is needed to bear such heavy loads and traffic near the facilities.

Previous research in biomass and ethanol usage has pointed out the importance of designing access roads or considering the capacity of access roads to the plant $[30,31]$. However, the existing literature, to the authors' knowledge, does not illustrate how loads can be calculated or access roads be designed for these facilities. Furthermore, research that has focused on wind farm technology suggests that local roads should handle the heavy construction loads from the wind mill parts [32-36]. On one hand, the focus has been on detailed design methodologies aiming to handle these loads, while on the other hand, guidelines to develop temporary access roads for wind farms were also presented [37].

As illustrated herein, the aforementioned design problems are solved using existing design guides, such as the American Association of State Highway and Transportation Officials (AASHTO) method. However, such methods may often be intricate, which would inevitably require consultation with expert designers. Even though third-party expert consultation is welcome, local authorities generally do not have the necessary funds for this process.

This paper aims to develop tools that can be used by local government agencies in quantifying the effects of proposed sustainable energy projects on their local road networks. The tools are designed and developed, bearing in mind that local agencies do not typically employ personnel with specific expertise in pavement analysis and design. These tools are therefore expected to assist local agency personnel in determining appropriate pavement sections and quantifying their costs. The paper is organized as follows. First, background information on renewable energy resources is given, along with biofuel transportation practices. Next, the method and data are presented, followed by the design development description of the proposed tool. Finally, the tool validation results are discussed.

The contribution of this paper lies in the development of local roadway infrastructure design guidelines associated with the construction and operation of sustainable energy source facilities, such as ethanol plants, biomass plants, and wind farm facilities. The proposed procedure is designed to be simple and is accompanied by handson tools to assist local government engineers in evaluating and in quantifying the probable effects of the construction and operation of a sustainable energy facility in their jurisdiction. Therefore, the procedure is anticipated to provide designs capable of withstanding heavy traffic loads, while, at the same time, it has the potential to quantify the effects that new sustainable energy source facilities may have on local road networks.

\section{Renewable energy resources}

In order to better comprehend the local effects of the construction and operation of sustainable energy projects, such as ethanol, biodiesel, biomass, and wind energy, some background information is briefly presented. Ethanol can be produced from a number of agricultural products, such as sugar and starch [38]. The ethanol production process yields several byproducts, such as dried distillers grains with solubles (DDGS), which are a high-nutrient feed valued by the livestock industry [39]. Ethanol demand is difficult to capture, given its dual nature, i.e., being both an additive to and a substitute for gasoline. However, the market for ethanol significantly increased (over 500\%) when flexible fuel vehicles (FFV) were made available to the public $[21,39,40]$. In Indiana, there are 11 ethanol plants, plus 2 under construction (see Figure 1).

Biomass is a plant matter grown to generate electricity or produce heat, with agricultural waste being the most common type of solid biomass that can be used as a source of energy [41]. Biomass currently provides about $10 \%$ of the world's primary energy supplies, most being used in developing countries in the form of fuel wood or charcoal for heating and cooking $[42,43]$. In the USA, $85 \%$ of the wood production industry waste is used for power generation, with approximately 80 operating biomass power plants (and 40 operable but idle plants) located in 19 states across the country [44]. Demand for power derived from biomass is generally increasing, having surpassed hydropower as the largest domestic source of renewable energy [45]. In Indiana, there is currently one biomass plant near Milltown in Crawford County [46].

The power of the wind can be harnessed and converted to electricity by the use of tower-mounted wind turbines. Wind turbines can be used to produce electricity for a single home or building, or they can be connected to an electricity grid for more widespread electricity distribution. Wind energy is not only 'green' but also cost effective when compared to other sources of electricity in the USA. The growing wind power market has attracted many energy corporations to the field $[47,48]$. In the USA, not all regions have wind speeds that are high enough to support wind energy production [49]. However, a recent study showed that building wind farms on only $3 \%$ of the area of the USA will produce enough electricity to meet all US energy demands [50]. In Indiana, there are currently 18 wind farms in operation, with over a 1,500 MW of wind electricity-generating capacity [51]. Indiana has the potential to produce $150,000 \mathrm{MW}$ of electricity from wind farms [51]. 


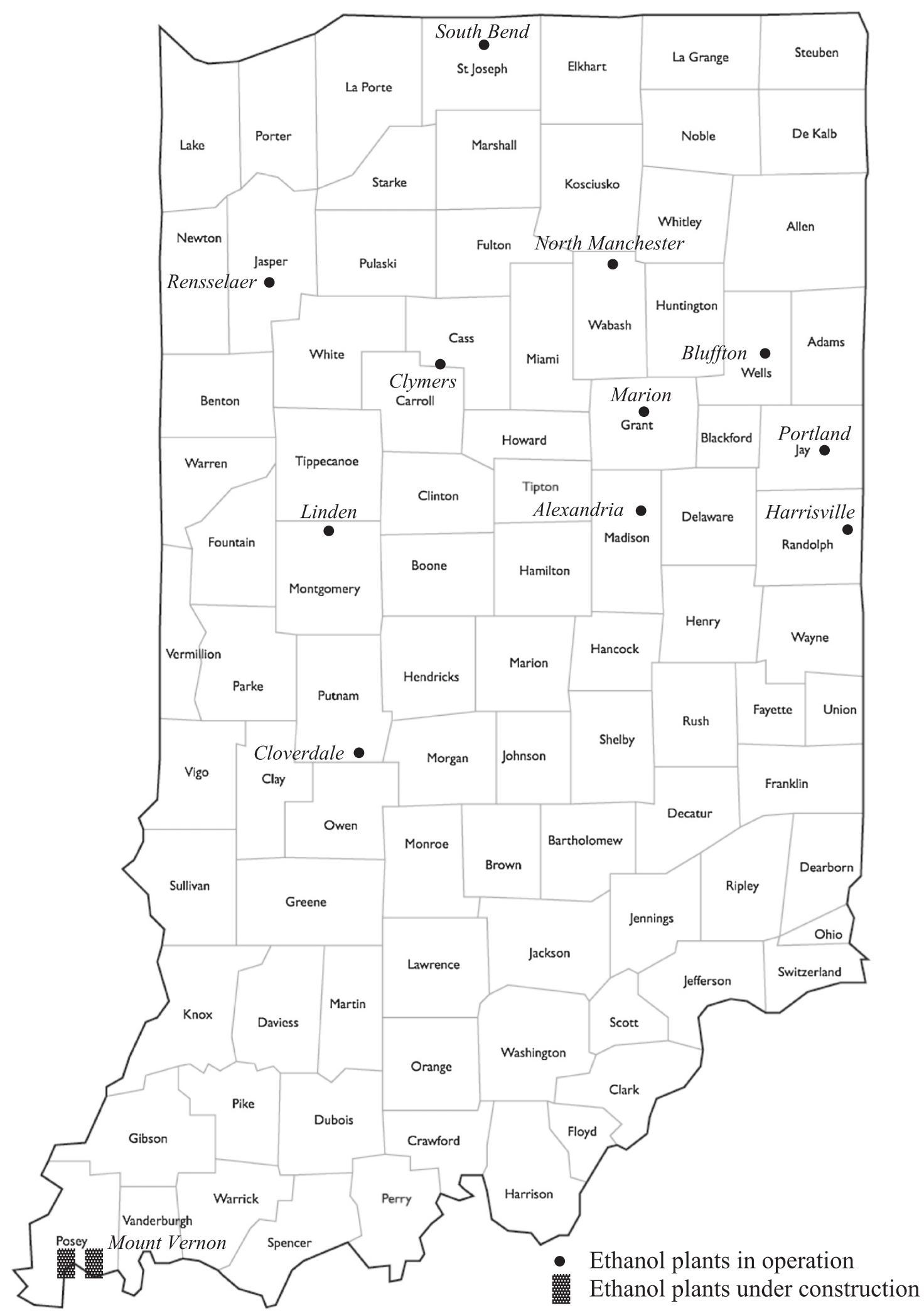

Figure 1 Ethanol plants in Indiana. 


\section{Transportation of biofuels}

Biofuels can be transported by trucks, rail, or barge. Trucks are used when the material needs to be transported from one mode to another. Rail transportation is effective for long hauls, while barges are the least expensive transport method. Barges can carry large amounts to export terminals, and then ocean vessels are used to carry them to foreign markets. Transportation of biofuels using pipelines is limited in the USA due to the adverse impact of the former (mostly their chemical properties) on the pipeline integrity and safety. Also, pipelines are not largely available where biofuel plants are located. However, pipelines are a feasible option for the transportation of conventional fuel types. Air transport is not a viable option either, due to its high cost.

From a capacity standpoint, a truck can accommodate approximately 25,000 liters, a railcar approximately 95,000 liters, and a barge approximately 1,500,000 liters. On the other hand, it would not be economically effective to use rail or barges to transport biofuels to short distances, such as locations within less than $80-\mathrm{km}$ distance from the facility [52]. In general, truck transportation is considered to be an efficient mode of transportation up to a distance of $500 \mathrm{~km}$ [52]. A railcar can transport the freight 2.5 times farther than a truck, for the same cost per liter, whereas barges can move freight across long distances and oversees (e.g., from the Midwest to the Gulf).

Rail is used to transport $41 \%$ of US corn exports and $14 \%$ of corn domestically [53]. In 2005, rail was the primary transportation mode for ethanol, shipping $60 \%$ of ethanol produced, or approximately 11 billion liters. In comparison, trucks shipped 30\%, and barges 10\%. Although trucks are used to ship most of the corn used by ethanol plants, some of the newer and larger plants use rail for inbound corn shipments [54].

Barges move approximately $5 \%$ to $10 \%$ of ethanol, in addition to the DDGS and fertilizers necessary for the production of corn. Barges also move $44 \%$ of all grain exports. In 2007, barges moved 55\% of corn to ports, and $1 \%$ of corn to processors, feed lots, and dairies [54]. An issue with barge transportation is related to the occasional inadequacy of water depths that can lead to higher transportation costs. Seasonal effects on barge transportation may also decrease the barge's moving capacity (e.g., at a 2.75-m draft, if a barge has 1,500 tons of capacity, every $2.5 \mathrm{~cm}$ of reduced draft will result in 17 tons of reduced capacity) [53].

In the Midwest, inbound corn being delivered to the processing facility is most typically delivered by trucks from corn farms within an $80-\mathrm{km}$ radius. Standard gasoline tanker trucks (DOT MC 3066 Bulk Fuel Haulers) are typically used to ship ethanol outbound from the plants to the blending terminals. The total number of independently operated tank trucks is approximately 10,000, excluding the tanker truck fleets that are owned by petroleum companies [55].

\section{Methods}

The objective of this paper is to develop a design methodology to assist local agencies in designing suitable pavements for sustainable energy projects served by local roads. In order to ensure a reliable pavement design, the first step is to collect accurate data with respect to the operation and traffic generation of sustainable energy projects. Development of the design tools is completed based on the following criteria: the tools should (a) be simple and easy to use; (b) require minimum input from the user and, at the same time, allow for more experienced users to input more detailed data; and (c) be able to produce several alternative pavement sections, when applicable. The output of the study involves worksheetbased pavement design procedures, one for ethanol and biomass plants, and a second for wind farms. These tools offer a user-friendly interface and several levels of input regardless of the expertise of the user.

The design development phase is based on various design guides and design elements that have been proven useful in the design of specialized pavements for sustainable energy projects. The design guides considered are the AASHTO Pavement Design Guide (for flexible and rigid pavements and for low-volume road design), the Asphalt Institute Pavement Design Guide, the Mechanistic-Empirical Pavement Design Guide (MEPDG), and the Portland Cement Association (PCA) [56-59]. Reviewing of these sources shows that rigid pavement design is not typically used in the design of local lowvolume roads. Thus, the AASHTO Rigid Pavement Design Guide and the PCA Pavement Design were not utilized in the proposed overall design methodology. The MEPDG was found to be complex and was not geared toward lowvolume roads and was therefore not used either. The AASHTO flexible pavement design was utilized due to its simplicity, versatility, and robustness. The AASHTO lowvolume road design was also utilized in the ethanol and biomass worksheet. As for the wind farm worksheet, the Asphalt Institute's Manual Series No. 23 (MS-23), 'Thickness Design: Asphalt Pavements for Heavy Wheel Loads' was the only design guide that addressed the large, onetime loads expected during the construction of wind farm facilities [60].

As a final step, the proposed design methodology is tested to ensure that it produces realistic results. Ideally, the proposed design methodology would be validated by building a road conforming to the design methodology, then monitor it over several years, and determine whether it fails prematurely. Obviously, this falls out of the scope of the current study. Instead, the proposed methodology is validated by comparing it to in-service designs currently 
servicing sustainable energy projects. If the simplified proposed design provides an output that falls close to the outputs of the designs in place, the proposed design is considered adequate. This, of course, does not guarantee an optimum design; it suggests, though, that the developed designs are approximating actual design results.

\section{Interviews with local officials}

As part of the data collection process, interviews were conducted with Indiana's local road agency representatives in counties where biomass plants, ethanol plants, or wind farm facilities are located. The interviews entailed a set of questions about the provided provisions in anticipation of the increased traffic and the current condition of the road network. To that end, 12 counties that have ethanol and biomass plants were interviewed. Of those 12 , only 4 had performed any type of upgrade to their local roads in anticipation of increased traffic. Table 1 summarizes the representatives' responses.

Traffic associated with ethanol and biomass plants can be classified as follows: (a) incoming traffic handling raw materials and (b) outgoing traffic handling product distribution. Incoming traffic is mainly composed of trucks, while outgoing traffic is composed of rail and truck traffic, in most cases. For this reason, plants are typically located near major highways and rail sites. In Indiana, all plants are located within $4 \mathrm{~km}$ from the nearest state highway or interstate and within $1.1 \mathrm{~km}$ from the nearest rail freight facility. Of all the plants, $85 \%$ are located within $1.6 \mathrm{~km}$ of a state highway. Of all operating ethanol and biomass plants in Indiana, 30\% are located adjacent to a main highway, whereas $23 \%$ of all operating ethanol and biomass plants in Indiana have rail tracks leading into their facility. On average, the plants in Indiana are $0.87 \mathrm{~km}$ away from a state highway and $0.5 \mathrm{~km}$ from a railroad.

County officials and plant managers expected that all truck traffic would use the nearby state highways or interstates. Thus, no significant upgrades were performed on local roads. In many cases, the expectation that trucks would utilize the state highways or interstates was not validated. Truck drivers use the shortest route unless otherwise instructed, which may or may not be a state highway or interstate. Also, farmers delivering raw materials to the plant came from all directions. This entailed utilizing county roads.

Local county highway representatives were interviewed in several counties in Indiana, in which wind farms are located. In both cases, the wind farm developers signed a road use agreement with the county specifying that the developers are responsible for the road condition. The developers agreed to return the roadways used in the wind farm construction process to their original condition and further performed significant upgrades to the local roads.
However, detailed information was only available from White County, which was used in the validation process.

Note that road use agreements typically include warranty clauses, which provide an assurance to the owner that the product/service will serve its useful life without failure, and if it does not, the contractor will repair or replace the product (for specifics on roadway preservation through public-private partnerships, see [61-69]). In the case of White County, a 2-year warranty was defined. Benton County defined a 1-year warranty on roads and a 5 -year warranty on drainage.

\section{Data}

\section{Biomass and ethanol plants}

The amount of traffic associated with an ethanol plant is directly related to the plant's capacity, most often measured in millions of liters per year (MLY). Because the plants are normally located to take advantage of locally produced raw materials, in this case corn, nearly all of the incoming raw material is delivered to the plant by tractor-trailers. The outgoing products are ethanol and DDGS. In Indiana, nearly all of the ethanol leaves the plant by train. The DDGS may be transported by train or truck, depending on local livestock markets. Plant capacities, amount of raw materials consumed, and plant production rates for each of the ethanol plants in Indiana are summarized in Table 2.

The amount of raw material consumed by a biomass plant is governed by the plant's capacity, the amount of electricity it can produce, and the plant's efficiency. Capacity is measured in megawatt electrical (MWe), while efficiency by the heat production rate is measured in watts per kilowatt-hour (W/KWh). Each material, when burned, produces a specific amount of heat energy measured in watts per kilogram $(\mathrm{W} / \mathrm{kg})$. Herein, a constant value of $2,746 \mathrm{~W} / \mathrm{kg}$ for all agricultural byproducts is adopted from Wiltsee [70]. The average heat rate of 140 biomass plants listed in the National Electric Energy System Database [71] was also used, which was calculated to be 4,462 W/KWh.

Unlike ethanol plants, biomass plants do not produce loaded, outgoing traffic. Raw materials are shipped to the plant and burned to generate electricity. The type of input materials varies and can be divided into four main types: woody plants, herbaceous plants/grasses, aquatic plants, and manures [72]. According to the local Indiana farmers, woody and herbaceous plants are the most commonly used raw materials in Indiana biomass plants, with the most typical being corn stover, wood chips, sawdust, and baled straw [72-74]. Each material has a different density, as shown in Table 3 . The less dense the material, the more space per kilogram it occupies; thus, more trucks are needed to transport less dense materials. This was taken into consideration when calculating loads associated with biomass plant operation. 
Table 1 Summary of local agency survey responses

\begin{tabular}{|c|c|c|c|}
\hline County & $\begin{array}{l}\text { Is the plant } \\
\text { operational? }\end{array}$ & General response & $\begin{array}{l}\text { Upgrades } \\
\text { performed }\end{array}$ \\
\hline Cass & Yes & No response & Unsure \\
\hline Grant & No & $\begin{array}{l}\text { No upgrades were performed on county roads. The nearest state highway } \\
\text { was widened to accommodate the large-radius turning paths of long trucks. } \\
\text { The plant does not have a county access road. }\end{array}$ & No \\
\hline Henry & Yes & $\begin{array}{l}\text { The plant is located right adjacent to a state highway; thus, there was no } \\
\text { need for any upgrades. However, roads are deteriorating quickly, and there } \\
\text { is no funding from the state or other sources. }\end{array}$ & No \\
\hline Jasper & Yes & $\begin{array}{l}\text { No provisions were needed because the plant is located adjacent to a } \\
\text { state highway. }\end{array}$ & No \\
\hline Jay & Yes & $\begin{array}{l}\text { Upgrades were performed on county roads. The plant created a tax } \\
\text { increment financing (TIF) district, and the new roads were paid for using } \\
\text { the money from the bonds sold. Upgrades included widening and } \\
\text { resurfacing of a section of a county road. The main problem is that truck } \\
\text { drivers do not always use that route; thus, other roadways may deteriorate. }\end{array}$ & Yes \\
\hline Kosciusko & Yes & $\begin{array}{l}\text { The Highway supervisor expressed concern about the highways. Attempts } \\
\text { were made to get funds to perform repairs. No legal agreement between } \\
\text { the plant and the county was made }\end{array}$ & No \\
\hline Lake & No & No response & No \\
\hline LaPorte & No & No response & No \\
\hline Madison & Yes & No response & Unsure \\
\hline Montgomery & Yes & No response & No \\
\hline Posey & Yes & $\begin{array}{l}\text { There are two plants; one is adjacent to a state highway, the other is not. } \\
\text { The latter required road upgrades. The upgrades were paid for through } \\
\text { setting up a TIF district. Also, there were two low-volume roads that the } \\
\text { plant wanted to build a bridge over. The county engineers were able to } \\
\text { reach to an agreement with the commissioners to close these two roads, saving } \\
\text { the expense of building an overpass. In return, the county received one million } \\
\text { dollars which they used to repair and upgrade highways. The upgrades } \\
\text { included mainly } 5 \text { to } 7.5 \mathrm{~cm} \text { of resurfacing on access roads. }\end{array}$ & Yes \\
\hline Putnam & No & No response & No \\
\hline Randolph & Yes & $\begin{array}{l}\text { The plant built a private access road to a county road that was partly } \\
\text { upgraded. The county is currently working on an agreement with the } \\
\text { plant to upgrade the roads used by farmers. }\end{array}$ & Yes \\
\hline Shelby & Yes & No response & Unsure \\
\hline Wabash & Yes & $\begin{array}{l}\text { The county established a TIF district in the area to be developed. The } \\
\text { county performed road upgrades which included digging up the existing } \\
\text { pavement, placing a 33- to 38-cm Portland cement-stabilized soil and } \\
\text { HMA on top. The project cost was } \$ 1.2 \text { million. The county was later } \\
\text { reimbursed by the plant (as agreed before the start of the project by } \\
\text { selling TIF district bonds). The county also received an economic } \\
\text { development stimulus from the state of Indiana. }\end{array}$ & Yes \\
\hline Wells & Yes & $\begin{array}{l}\text { There were no upgrades performed. However, there were discussions at } \\
\text { the time of construction that the plant had a budget set for upgrading } \\
\text { the roadway. Due to technical difficulties on the county/city side, the roads } \\
\text { were not upgraded. The plant did not spend any of the allocated budget. } \\
\text { The county engineers tried to mitigate the damage by channelizing the } \\
\text { truck traffic produced by the plant onto roadways that could accommodate the } \\
\text { traffic. The county engineers provided this channelization through verbal } \\
\text { coordination with truck companies and drivers. The highway supervisor } \\
\text { stated that the truck companies were very cooperative. }\end{array}$ & No \\
\hline
\end{tabular}

\section{Wind farms}

The increased truck traffic associated with wind farm facilities is mostly limited to construction traffic, which can be divided into transportation of construction materials (concrete, aggregates, and steel reinforcing), transportation of construction equipment (cranes), and transportation of wind turbine components (nacelle, rotor, blades, and tower sections). The construction materials represent the heaviest loads per truck axle. The turbine components can be heavy, but additional axles are added to 
Table 2 Indiana ethanol plant data

\begin{tabular}{|c|c|c|c|c|c|c|}
\hline & County & $\begin{array}{l}\text { Annual liters of } \\
\text { ethanol produced } \\
\text { (millions) }\end{array}$ & $\begin{array}{l}\text { Annual bushels } \\
\text { of corn used } \\
\text { (millionsa })\end{array}$ & $\begin{array}{l}\text { Corn used per liter } \\
\text { of ethanol produced } \\
\text { (bushels) }\end{array}$ & $\begin{array}{l}\text { Annual tons of } \\
\text { DDGS produced } \\
\text { (thousands) }\end{array}$ & $\begin{array}{l}\text { Annual tons of DDGS } \\
\text { produced per liters of } \\
\text { ethanol produced (millions) }\end{array}$ \\
\hline \multicolumn{7}{|l|}{ Plant } \\
\hline Anderson Ethanol & Cass & 416 & 39 & 0.0937 & 354 & 0.850 \\
\hline Cardinal Ethanol & Randolph & 379 & 37 & 0.0977 & 321 & 0.848 \\
\hline Central Indiana Ethanol & Grant & 151 & 15 & 0.0991 & 145 & 0.958 \\
\hline Indiana Bio-Energy & Wells & 416 & 37 & 0.0889 & 321 & 0.771 \\
\hline $\begin{array}{l}\text { Iroquis Bio-Energy } \\
\text { Company }\end{array}$ & Jasper & 151 & 15 & 0.0991 & 129 & 0.852 \\
\hline New Energy Corp. & St. Joseph & 379 & 37 & 0.0977 & 328 & 0.866 \\
\hline POET & Jay & 246 & 24 & 0.0975 & 193 & 0.784 \\
\hline POET & Madison & 227 & 22 & 0.0969 & 193 & 0.850 \\
\hline POET & Wabash & 246 & 24 & 0.0975 & 209 & 0.849 \\
\hline $\begin{array}{l}\text { Valero Energy (formerly } \\
\text { Vera-Sun) }\end{array}$ & Montgomery & 379 & 37 & 0.0977 & 350 & 0.925 \\
\hline Altra (not operating) & Putnam & 227 & 22 & 0.0969 & 192 & 0.845 \\
\hline Abengoa Bioenergy & Posey & 333 & 32 & 0.0961 & 282 & 0.847 \\
\hline Total & & 3,551 & 341 & 1.16 & 3,017 & 10.25 \\
\hline Average & & 296 & 28 & 0.10 & 251 & 0.85 \\
\hline
\end{tabular}

${ }^{a}$ One bushel of corn weighs about $25 \mathrm{~kg}$.

the truck trailer as needed so as to comply with axle weight limits. In most cases, the length of the turbine components is the most critical concern. Wind turbine components, such as blades and tower sections, are extremely long and require long trucks to haul them. Blades are typically $45 \mathrm{~m}$ in length and weigh $11,340 \mathrm{~kg}$ [26]. While the weight is distributed over a large number of axles, the challenge is making sure that trucks have sufficient turning radii when using local roads. Table 4 summarizes the weight and truck axles needed for various wind turbine components [71].

The erection of wind turbines includes two major activities: off-loading and stacking out. Off-loading normally requires a 200-ton crawler or hydraulic crane. Stack-out requires a 400-ton crane [75]. Both cranes are transported in pieces and assembled on site. Table 5 summarizes the weight of each component and the number of truck axles required to carry it. Each crane is assembled in 20 to 25 truck trips, which are performed at least twice (assembling and disassembling) in

Table 3 Biomass raw material densities

\begin{tabular}{lc}
\hline Material & Density $\left(\mathbf{k g} / \mathbf{m}^{\mathbf{3}}\right)$ \\
\hline Corn stover & 128.15 \\
Wood chip & 200.23 \\
Sawdust & 120.14 \\
Baled straw & 150.57 \\
\hline
\end{tabular}

the project lifetime, regardless of the number of wind turbines being built $[26,76,77]$.

As mentioned earlier, the heaviest load associated with wind farm construction is the construction materials. Wind tower foundations require 282 to $480 \mathrm{yd}^{3}$ of concrete and 20 to 38 tons of steel reinforcement [75]. Truck traffic is also generated by the need to transport aggregates to the site. Table 6 presents the number of trucks needed to construct the foundation of a single turbine and the weights of each construction material used [23]. Finally, data on local pavement construction materials were collected from local suppliers and used in the proposed design process. One of the design outputs is the cost of the recommended pavement. The specific gravity and cost data collected and utilized in the analyses are illustrated in Table 7.

\section{Results and discussion}

\section{Design development}

Two MS Excel-based pavement design procedures (Excel worksheets) were developed, one for ethanol and biomass plants, and a second for wind farms. Both worksheets follow the logic outlined in Figure 2.

\section{Ethanol and biomass design specifications}

The ethanol and biomass design procedure is based on the standard AASHTO Pavement Design Guide [56]. As discussed previously, ethanol and biomass plants produce significant traffic, which is mainly composed of 
Table 4 Truck information for various wind turbine components

\begin{tabular}{|c|c|c|c|c|c|}
\hline Component & Weight (kg) & $\begin{array}{c}\text { Longest } \\
\text { dimension }(\mathrm{m})\end{array}$ & $\begin{array}{l}\text { Minimum number of truck axles } \\
\text { needed to carry component }\end{array}$ & $\begin{array}{l}\text { Weight per axle } \\
\text { (kg/axle) }\end{array}$ & $\begin{array}{l}\text { Weight per tire } \\
\text { (kg/tire) }\end{array}$ \\
\hline Base section & 41,958 & 14.66 & 4 & 10,490 & 2,622 \\
\hline Lower-middle section & 41,241 & 19.81 & 6 & 6,874 & 3,789 \\
\hline Upper-middle section & 28,111 & 19.90 & 6 & 4,685 & 2,583 \\
\hline Top section & 28,876 & 22.59 & 6 & 4,813 & 2,653 \\
\hline Hub & 17,010 & 3.84 & 3 & 5,670 & 3,125 \\
\hline Blades & 6,486 & 33.99 & 6 & 1,081 & 596 \\
\hline Rotor & 32,024 & 70.47 & 6 & 5,337 & 2,942 \\
\hline Nacelle & 57,153 & 8.81 & 3 & 19,051 & 10,500 \\
\hline
\end{tabular}

trucks. The traffic produced is typically above one million equivalent single axle loads (ESAL) over a 20-year period, which merits a design governed by pavement fatigue standards.

There are primary and secondary design inputs, which are summarized in Table 8. Primary inputs are projectspecific, which vary significantly from one project to another. Secondary inputs are approximately constant across projects, either due to the nature of these factors, or because they tend to be standardized. These inputs are set at default, but can be customized by the user if desired.

In order to simplify the design process, a number of assumptions are made. It is important to note that these assumptions could be easily changed by the user if so desired. The following are the assumptions considered in this design procedure:

- The capacity of a typical truck is assumed to be $90.6 \mathrm{~m}^{3}$.
- An average number of bushels of corn (0.091 bushels/liter of ethanol) is used to calculate the amount of corn needed to supply the ethanol plant: Unit analysis ( 1 bushel $=25 \mathrm{~kg}$ )

For one million liters of ethanol, 91,000 bushels are needed (0.091 × 1,000,000); using a 25-ton $(25,000 \mathrm{~kg})$ truck, the number of trucks needed per day in a year is equal to $91,000 \times 25 /$ $(25,000 \times 365)=0.25$.

- Using unit analysis, it is found that for each one million liters per year of ethanol to be produced, 0.25 trucks per day are needed to supply the plant. The number of ethanol tanker trucks is calculated, assuming that tankers haul on average 30,000 liters. Using an ethanol density of $0.789 \mathrm{~kg} /$ liters, the weight per truck is calculated as $23,000 \mathrm{~kg}$ [55].

- One million liters of ethanol has a byproduct of 845 tons of DDGS and a truck can haul approximately 25 tons of distiller's grain [55], leading to a factor of 0.0926 trucks per day:

Table 5 Crane components

\begin{tabular}{|c|c|c|c|c|c|c|}
\hline \multirow[t]{2}{*}{ Equipment } & \multicolumn{3}{|c|}{ 200-ton crane } & \multicolumn{3}{|c|}{ 400-ton crane } \\
\hline & Weight (kg) & $\begin{array}{c}\text { Number of } \\
\text { axles }\end{array}$ & $\begin{array}{l}\text { Weight per } \\
\text { tire (kg/tire) }\end{array}$ & Weight (kg) & $\begin{array}{c}\text { Number of } \\
\text { axles }\end{array}$ & $\begin{array}{l}\text { Weight per } \\
\text { tire (kg/tire) }\end{array}$ \\
\hline Basic crane & 39,689 & 4 & $2,480.58$ & 39,612 & 4 & $2,475.76$ \\
\hline Car-body and adapter & N/A & N/A & N/A & 28,161 & 3 & $2,346.77$ \\
\hline Crawler assembly & 19,622 & 4 & $1,226.40$ & 32,665 & 4 & $2,041.59$ \\
\hline Counterweight tray & 9,548 & 3 & 795.68 & 19,958 & 3 & $1,663.17$ \\
\hline Upper-center counterweight & 10,659 & 3 & 888.28 & 8,165 & 3 & 680.39 \\
\hline Upper-side counterweight & 7,938 & 3 & 661.49 & 6,804 & 3 & 566.99 \\
\hline Lower car-body counterweight & 9,979 & 3 & 831.59 & 13,608 & 3 & $1,133.98$ \\
\hline Upper car-body counterweight & 8,165 & 3 & 680.39 & $\mathrm{~N} / \mathrm{A}$ & $\mathrm{N} / \mathrm{A}$ & $\mathrm{N} / \mathrm{A}$ \\
\hline $9 \mathrm{~m}$ boom butt & 4,910 & 3 & 409.18 & 21,609 & 3 & $1,800.76$ \\
\hline 12 m boom top & 2,544 & 3 & 212.02 & 5,595 & 3 & 466.25 \\
\hline $3 \mathrm{~m}$ boom insert & 971 & 3 & 80.89 & $\mathrm{~N} / \mathrm{A}$ & $\mathrm{N} / \mathrm{A}$ & $N / A$ \\
\hline $6 \mathrm{~m}$ boom insert & 1,397 & 3 & 116.42 & 2,563 & 3 & 213.57 \\
\hline
\end{tabular}


Table 6 Wind-tower foundation construction materials

\begin{tabular}{lccc}
\hline $\begin{array}{l}\text { Construction } \\
\text { material }\end{array}$ & $\begin{array}{c}\text { No. of trucks } \\
\text { required }\end{array}$ & $\begin{array}{c}\text { Truck } \\
\text { loads } \mathbf{( k g})\end{array}$ & $\begin{array}{c}\text { Load per } \\
\text { tire } \mathbf{( k g})\end{array}$ \\
\hline Aggregate & 10 & 22,680 & 5,670 \\
Concrete & 20 to 40 & 22,680 & 5,670 \\
Steel & 1 & 18,144 & 4,536 \\
\hline
\end{tabular}

\section{Unit analysis}

For one million liters of ethanol, 845 tons of DDGs is needed; using a 25-ton (25,000 kg) truck, the number of trucks needed per day in a year is equal to: $845 /(25 \times 365)=0.0926$.

- The ESAL of the trucks are calculated using the fourth power law load equivalency factor (LEF). This law uses the weight over a constant based on axle type raised to the fourth power [78]:

$\mathrm{LEF}=\left(\frac{\text { Weight of axle }}{\text { Weight of constant }}\right)^{4}$

$E S A L=L E F \times$ Number of vehicles with that axle weight

For a single axle, the constant used is $8,160 \mathrm{~kg}$. For a tandem axle, the constant used is $15,060 \mathrm{~kg}$.

- For the biomass facility, the weight of product produced is calculated using typical heat and production rates: 4,103 W/ $\mathrm{kWh}$ heat rate and $2,746 \mathrm{~W} / \mathrm{kg}$ fuel production rate.

- For biomass facilities, the densities of the raw materials are used to calculate the weight and number of trucks going into the plant. The densities of these raw materials are listed in Table 3.

- The AASHTO design guide's [56] ESAL equation is used to find the pavement's structural number:

$$
\begin{aligned}
\log W_{18}= & Z_{\mathrm{R}}+S_{0}+9.36(\log (\mathrm{SN}+1)-0.2) \\
& +\frac{\log \frac{\Delta \mathrm{PSI}}{4.2-1.5}}{0.4+\frac{1,094}{(\mathrm{SN}+1)^{5.19}}}+2.32\left(\log \left(M_{R}\right)-8.07\right),
\end{aligned}
$$

where $W_{18}=$ ESAL (reflects road traffic), $Z_{R}=$ standard normal deviation (reflects the reliability of design),
$S_{0}=$ standard deviation (reflects variability of pavement material), $\Delta \mathrm{PSI}=$ reflects the difference between pavement condition right after construction and the end of its service life, and $M_{\mathrm{R}}=$ resilient modulus (PSI) (reflects subgrade strength).

The design normally consists of three layers. Layer coefficients, $a$, are assumed to take the following values: $a_{1}=0.4$ (in the range of 0.2 to $0.4 ; 0.4$ is typically used), $a_{2}=0.14$ (recommended by AASHTO for granular base layers), and $a_{3}=0.11$ (recommended by AASHTO for granular sub-base layers). Drainage coefficients, $m$, are assumed to take the following values: $m_{2}=0.8$ and $m_{3}=0.8$ (these values reflect fair drainage with $75 \%$ reliability). Initial pavement serviceability $(P O)$ is assumed to be 4.2 (this value is the AASHTO design guide [56] recommended value for flexible pavements). The resilient modulus introduced in the design's internal calculations is a function of the California bearing ratio or CBR (a penetration test for the evaluation of the mechanical strength of road subgrades and base courses, with higher values representing harder surfaces) and is calculated using the following equation:

$$
M_{\mathrm{R}}=2,555\left(\mathrm{CBR}^{0.64}\right) \text {. }
$$

- The assumed specific gravities and costs of materials are listed in Table 7 . Note that these costs are highly recommended to be updated regularly to reflect actual costs.

Table 9 provides a summary of all input parameters, default values, and assumptions.

For ethanol plants, the number of trucks carrying products and raw material (or empty) is determined by multiplying the amount of ethanol produced per year (in MLY) by the number of trucks needed to ship one million liters of ethanol in a day (i.e., 0.25 for ethanol, and 0.0926 for the added value product DDG) or dividing by the average liters of ethanol carried by each truck daily (30,000 liters/ truck). The weight of each truck is calculated using the weight of the truck empty plus the weight of the cargo (raw materials or products carried). The steering axle has a fixed load. Driver and trailer axles share the weight of the load equally. The loads are converted to load equiva-

\begin{tabular}{|c|c|c|c|c|c|}
\hline Material & Specific gravity & Density $\left(\mathrm{kg} / \mathrm{m}^{3}\right)$ & Tons/lane-km/cm & Price/ton/lane & Price/lane-km/cm \\
\hline Hot mix asphalt & 2.65 & 2,643 & 106.66 & $\$ 90$ & $\$ 9,599$ \\
\hline Compacted dense aggregate & 2.75 & 2,739 & 110.82 & $\$ 13$ & $\$ 1,441$ \\
\hline Coarse aggregate & 2.45 & 2,435 & 98.83 & $\$ 9$ & $\$ 889$ \\
\hline Excess excavation & & & & & $\$ 245$ \\
\hline
\end{tabular}
lency factors (LEF) using Equation 1.

Table 7 Pavement construction materials, specific gravities, and costs 


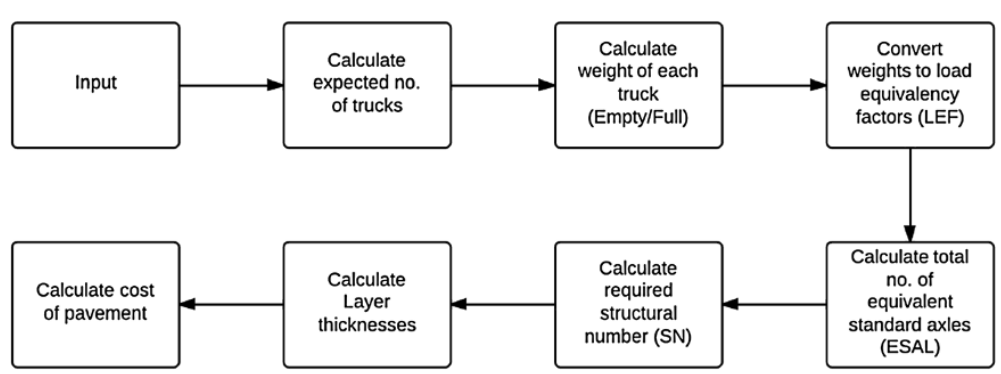

Figure 2 Conceptual illustration of the pavement design procedures.

Table 8 Primary and secondary inputs needed for the ethanol and biomass procedure

\begin{tabular}{ll}
\hline Primary inputs & Description \\
\hline Plant capacity & $\begin{array}{l}\text { This value represents the maximum amount } \\
\text { of biofuel that could be produced by the } \\
\text { plant considered. This value should be } \\
\text { reported in million liters per year for ethanol } \\
\text { plants and megawatts electrical (MWe) for } \\
\text { wind farms. }\end{array}$ \\
$\begin{array}{ll}\text { Capacity factor for } \\
\text { biomass plants }\end{array}$ & $\begin{array}{l}\text { Biomass plants produce power but are not } \\
\text { exclusively consistent in doing so. The capacity } \\
\text { factor is a percentage that represents the } \\
\text { average power output of a plant. It ranges } \\
\text { from 15\% to 100\%. When this value is } \\
\text { unknown, an average value of } 67 \% \text { is assumed. }\end{array}$
\end{tabular}

Design period

California bearing ratio (CBR)
The amount of time the road is expected to remain in service without major rehabilitation. This value is typically 20 years; however, for county roads, it can be lower.
Biomass fuel type

Reliability $(R \%)$

strength of the underlying soil. To get the actual field CBR of the soil, soil bores need to be drilled in the construction location. However, the value can be closely estimated by knowing the type of soil in the area. Highway supervisors can resort to previous experience or soil maps to determine the soil type in the area.

index (Pt)
Ethanol plant products and raw materials

\section{Secondary inputs}

Description

Yearly growth factor

Biomass fuel type

Overall standard deviation
If the plant is expected to increase its capacity in the future, the designer may add a reasonable growth factor. However, it is uncommon for a plant to be built and have its capacity increased later on in its service life. The default value is $0 \%$.

Amount of corn hauled to the plant by trucks, as opposed to be transported by another means, or grown within the plants' grounds, thus not using any local roads. Therefore, the default value assigned is 100\%.

Ethanol hauled from the plant by trucks, as opposed to stored or sold locally. Most ethanol plants are located close to rail freight tracks. For this reason, most (if not all) of the ethanol production will be shipped by rail. The assigned default value is conservatively set to $20 \%$.

DDGS hauled from the plant by trucks. This has a default value of $20 \%$.

Biomass fuel can be produced using various components and ratios of these components. Different component raw materials have different weights. It is important to determine the different percentages of each raw material to avoid underestimating the weight of incoming trucks. The four typical components are corn stover, wood chips, saw dust, and baled straw. Each is set at a default value of $25 \%$.

The designer should choose the level of reliability of the design. For local county roads, the reliability is typically low. This value ranges from $50 \%$ to $99 \% ; 75 \%$ is the default value.

This is the value that reflects the condition of the pavement at the end of its service life. This value ranges from 3 (for major highways) to 1.5 (minimum). The default value is 2 , as recommended for county roads by the AASHTO design guide [49].

This number reflects the variability within the pavements' materials. It typically ranges from 0.3 to 0.5 . A value of 0.5 is recommended by the AASHTO design guide [49] and is set as the default value. 
Table 9 Ethanol and biomass worksheet input parameters

\begin{tabular}{|c|c|c|c|}
\hline Parameter & Default value & Range & Comments \\
\hline Plant capacity & User input & $\mathrm{N} / \mathrm{A}$ & Input in MLY or MWe \\
\hline Design period (years) & 20 & 1 to 40 & $\begin{array}{l}\text { A service life of } 20 \text { years should be adequate for low-volume } \\
\text { pavements. }\end{array}$ \\
\hline Yearly growth factor (\%) & 0 & 0 to 100 & $\begin{array}{l}\text { This is capacity growth associated with the plant alone. It is } \\
\text { not expected that a plant at full capacity will increase its } \\
\text { capacity with time; thus, this value is set at } 0 \% \text {. }\end{array}$ \\
\hline \multicolumn{4}{|l|}{ Ethanol plants only } \\
\hline Percentage of corn used that is trucked to the plant (\%) & 100 & 0 to 100 & The model assumes all corn is supplied to the plant by trucks. \\
\hline Ethanol leaving the plant by truck (\%) & 20 & 0 to 100 & $\begin{array}{l}\text { The model assumes 20\% ethanol is hauled from the plant } \\
\text { in trucks. }\end{array}$ \\
\hline Dried distillers grain leaving the plant by truck (\%) & 20 & 0 to 100 & $\begin{array}{l}\text { The model assumes most of the dried distiller grains leave the } \\
\text { plant by rail. }\end{array}$ \\
\hline \multicolumn{4}{|l|}{ Biomass plants only } \\
\hline Capacity factor (\%) & 66.6 & 19 to 100 & $\begin{array}{l}\text { The average capacity factor of biomass plants across the USA } \\
\text { is } 66.6 \% \text {. }\end{array}$ \\
\hline \multicolumn{4}{|l|}{ Fuel type for biomass } \\
\hline Corn stover (\%) & 25 & 0 to 100 & \multirow{4}{*}{$\begin{array}{l}\text { Each plant uses different raw materials with different densities. } \\
\text { This, in turn, affects the number of trucks supplying the } \\
\text { materials. Currently, there is no dominant material in Indiana, } \\
\text { thus the equal division. }\end{array}$} \\
\hline Wood chips (\%) & 25 & 0 to 100 & \\
\hline Sawdust (\%) & 25 & 0 to 100 & \\
\hline Baled straw (\%) & 25 & 0 to 100 & \\
\hline \multicolumn{4}{|l|}{ Structural parameters } \\
\hline California bear ratio & User input & $\mathrm{N} / \mathrm{A}$ & $\begin{array}{l}\text { CBR is then converted to resilient modulus }\left(M_{R}\right) \text { using Equation 4; } \\
\text { a value of } 3 \text { or less can be used for conservative results. }\end{array}$ \\
\hline Standard normal deviate (based on percent reliability), $Z_{R}$ & 75 & 50 to 99 & $\begin{array}{l}\text { The designer should choose the level of reliability of the } \\
\text { design. For local county roads, the reliability is typically } \\
\text { lower than high-volume roads. }\end{array}$ \\
\hline Terminal serviceability, $P_{\mathrm{t}}$ & 2 & 3.0 to 1.5 & $\begin{array}{l}\text { This is the value that reflects the condition of the pavement } \\
\text { at the end of its service life. The AASHTO design guide } \\
\text { recommends a value of } 2 \text { for county roads. }\end{array}$ \\
\hline Standard deviation, $S_{\circ}$ & 0.5 & 0.3 to 0.5 & $\begin{array}{l}\text { This number reflects the variability within the pavements' materials } \\
\text { A value of } 0.5 \text { is recommended by AASHTO design guide. }\end{array}$ \\
\hline
\end{tabular}

In biomass plants, raw materials are burned to produce electricity. Each kilogram of raw material can produce a certain amount of heat energy. Typically, $1 \mathrm{~kg}$ of biomass can produce 2,746 W of heat energy; this is labeled as the production rate. The heat is then used to convert liquid water into steam, which in turn, rotates a steam turbine to produce electricity. The amount of heat needed to produce $1 \mathrm{KWh}$ of electricity is the heat rate of the process. The heat rate is typically $4,103 \mathrm{~W} / \mathrm{KWh}$. The amount of material needed per day can be obtained by multiplying the heat rate by the number of KWh produced in a day and then dividing by the production rate.

The next step is to calculate the number of trucks needed to carry the raw material. First, the weight of each raw material is calculated; next, it is divided by its density and converted into volume. The total number of trucks is then calculated by dividing the total volume of that material by the capacity of each truck, which is typically $90.6 \mathrm{~m}^{3}$. The weight of each truck can be obtained by multiplying the total truck capacity $\left(90.6 \mathrm{~m}^{3}\right)$ by the density of the raw material used. The raw material used by the worksheet can be corn stover, woodchips, sawdust, and baled straw, or any combination of these. The loads are converted to LEF using Equation 1.

In both ethanol and biomass worksheets, the total number of ESAL is calculated by multiplying the LEF by the number of trucks in the design period that have that axle, and then by summing up all the ESAL.

The structural number (SN) for all layers is calculated using Equation 3. The thickness of each layer is calculated using the attained structural number, and the layer and drainage coefficients. The AASHTO [56] structural number equation is

$$
\mathrm{SN}=a_{1} D_{1}+a_{2} D_{2} m_{2}+a_{3} D_{3} m_{3}
$$

For full-depth asphalt, the depth of the layer is obtained by dividing $\mathrm{SN}$ by $a_{1}$. The worksheet calculates 
various layer thickness combinations. The first layer is initially set to the minimum recommended by AASHTO [56] for the number of ESALs attained. The base and sub-base are calculated by satisfying two simultaneous equations. The first is the structural number equation, and the second is the ratio of base to sub-base thickness set by the user. The tool computes various combinations of the three layer thicknesses: $D_{1}, D_{2}$, and $D_{3}$. The user can chose any combination or change the values to produce a unique design. For full-depth asphalt, the depth of the layer is obtained by dividing SN by $a_{1}$.

The worksheet automatically estimates the costs for the thickness combinations using the assumed cost values listed earlier. However, the users have the option of specifying their own costs.

\section{Wind farm design specifications}

Wind turbines have very large and heavy components. These components, when transferred to the wind farm location, can accelerate the deterioration of the road assets and their components. Similar to the ethanol and biomass procedure, there are two levels of input, primary and secondary. These are presented in Table 10

To simplify the design process, a number of assumptions are made. It is important to note that all these assumptions could be changed manually in the design guide spreadsheets. The following are the assumptions considered in the wind farm design procedure:

- One-time heavy wheel loads during construction: Use Asphalt Institute's manual 'Thickness Design: Asphalt Pavements For Heavy Wheel Loads'. The loads necessary for a single wind turbine to be built (components and construction) are shown in Tables 4 to 6 .

- Turbine loads based on a GE 1.5 s (1.5-MW design): Loads are assumed to be similar for all turbines near this size.
- The resilient modulus introduced in the design's internal calculations is calculated using Equation 4.

- The specific gravities and cost of materials assumed are listed in Tables 6 and 7.

Table 11 lists all input parameters and their default values, where applicable.

Traffic counts are calculated by multiplying the heaviest truck used for design, by the number of trucks per wind turbine (assumed 91), and by the number of wind turbines (inserted by the users). To estimate the layer structural numbers, two values are needed to be calculated: the tire coefficient, $a$, and the tire pressure. The tire contact area coefficient, $a$, is calculated as follows:

$$
a=\sqrt{(\text { Tire Contact Area } / \pi)}
$$

whereas the tire pressure, $p$, is calculated as

$$
p=\frac{\text { Maximum Load }}{\text { Tire Contact Area }} \text {. }
$$

The structural number is calculated as

$$
\mathrm{SN}=0.3 a\left(0.773 \ln (p)-2.535+\frac{15-M_{\mathrm{R}}}{10.5}(0.049 \ln (p)+0.116)\right) .
$$

To estimate costs of various alternatives, the cost of the calculated thicknesses is computed using the assumed cost values listed in Table 7 (the worksheet does this computation automatically); however, the users have the option of including their own cost values.

\section{Validation}

The ethanol and biomass worksheets are based on the AASHTO pavement design guide [56], inheriting its strong points and its limitations. For the purposes of developing a user friendly design procedure, the

\begin{tabular}{|c|c|c|c|}
\hline Primary inputs & Description & Secondary inputs & Description \\
\hline $\begin{array}{l}\text { Number of wind } \\
\text { turbines }\end{array}$ & $\begin{array}{l}\text { To transfer each wind turbine, a certain number of } \\
\text { trucks are required, which typically use the same } \\
\text { transfer routes. In the case that several turbines are } \\
\text { transferred by different routes, each route should } \\
\text { be designed for the number of turbines that will } \\
\text { be moved across. }\end{array}$ & Tire contact area & $\begin{array}{l}\text { Different tires have different contact areas. This value } \\
\text { could be obtained from the manufacturer. The load } \\
\text { and internal pressure are factors that affect and are } \\
\text { affected by these values. If this value is unknown, } \\
1,935 \mathrm{~cm}^{2} \text { is recommended as default. }\end{array}$ \\
\hline $\begin{array}{l}\text { California bearing } \\
\text { ratio (CBR) }\end{array}$ & $\begin{array}{l}\text { This value reflects the strength of the underlying } \\
\text { soil. To get the exact value, soil bores are needed } \\
\text { to be drilled in the construction location. However, } \\
\text { the value can be closely estimated by knowing the } \\
\text { type of soil in the area. Highway supervisors can } \\
\text { resort to previous experience or soil maps to } \\
\text { determine the soil type in the proximity. }\end{array}$ & & \\
\hline
\end{tabular}
AASHTO design method is preferred over the more

Table 10 Primary and secondary inputs needed for the wind farm procedure 
Table 11 Wind farm worksheet input parameters

\begin{tabular}{lcl}
\hline Parameter & Default value & Comments \\
\hline Number of turbines & User input & The number of wind turbines to be installed. \\
Soil CBR & User input & CBR is converted to resilient modulus $\left(M_{\mathrm{R}}\right)$ using Equation 4. \\
Tire contact area $\left(\mathrm{cm}^{2} / \mathrm{tire}\right)$ & 1,935 & $\begin{array}{l}\text { This value could be obtained from the manufacturer. One thousand nine } \\
\text { hundred square centimeters was used for dual-tire configurations [72,73]. }\end{array}$ \\
Maximum load per tire $(\mathrm{kg})$ & 4,536 & Only construction loads are considered. \\
\hline
\end{tabular}

recent mechanistic-empirical design method, as the former is well known for its empirical approach. Moreover, it does not need calibration or validation, because it is linked to the validated AASHTO design guide. For more conservative results, the reliability factor (ranges from $50 \%$ to 99.9\%) can be increased in the worksheet.

Finding structural data associated with local roads is a tedious task. However, Jay, Posey, and Wabash counties did collect the pavement layer thickness values after they were upgraded for the construction and operation of the biomass and ethanol plants. For the ethanol plant in Jay County, provisions were made to accommodate the new increased truck traffic, and the road was resurfaced; however, the assumptions made related to the preferred truck-driver routes fall short, causing excessive deterioration to the adjacent roads. For the ethanol plant in Posey County, to handle the excess traffic, the county resurfaced all access roads. Similarly, to accommodate the anticipated increase in traffic associated with the ethanol plant in Wabash County, a $1.2-\mathrm{km}$ road section was reconstructed. With these exceptions, the interviews with various county officials showed that there were generally no provisions made for ethanol and biomass plants due to their close proximity to state roads.

The second step in the validation process is to produce designs for these three counties using the developed worksheets. Table 12 presents the recommended pavement sections for each plant based on the ethanol and biomass worksheet, along with an estimated cost for each alternative. A CBR value of 3 , representing tilled farmland, was used for Jay and Posey counties, and a value of 2 (representing softer surfaces) was used for the Wabash County. The county highway engineers mentioned that the soil is weak in that particular area. A design period of 20 years was assumed in all three cases.

The final step in the validation process is to compare the pavements designed by the county engineers and private contractors, with the pavement designs proposed by the developed tool. Table 13 lists the capacities of various plants, and compares as-built thickness to those proposed by the worksheets. The structural numbers obtained by the worksheet are higher than the actual numbers from both cases. Wabash County pavements were designed by an engineering consulting firm. The other

Table 12 Ethanol and biomass worksheet results

\begin{tabular}{|c|c|c|c|c|}
\hline Design & Alternative 1 & Alternative 2 & Alternative 3 & Alternative 4 \\
\hline \multicolumn{5}{|c|}{ Jay County, POET Plant, capacity 65 MLY } \\
\hline Surface layer $(\mathrm{cm})$ & 7.62 & 8.89 & 10.16 & 10.16 \\
\hline Base layer (cm) & 26.67 & 15.24 & 30.48 & 19.05 \\
\hline Sub-base layer (cm) & 34.29 & 40.64 & 15.24 & 30.48 \\
\hline Pavement cost (\$) & 246,744 & 247,468 & 262,624 & 259,417 \\
\hline \multicolumn{5}{|c|}{ Posey County, Abengoa Bioenergy Plant, capacity 88 MLY } \\
\hline Surface layer $(\mathrm{cm})$ & 7.62 & 8.89 & 11.43 & 10.16 \\
\hline Base layer (cm) & 26.67 & 15.24 & 30.48 & 21.59 \\
\hline Sub-base layer (cm) & 35.56 & 44.45 & 15.24 & 30.48 \\
\hline Pavement cost (\$) & 249,060 & 254,417 & 282,769 & 266,306 \\
\hline \multicolumn{5}{|c|}{ Wabash County, POET Plant, capacity 65 MLY } \\
\hline Surface layer $(\mathrm{cm})$ & 7.62 & 8.89 & 12.7 & 10.16 \\
\hline Base layer (cm) & 29.21 & 15.24 & 30.48 & 25.4 \\
\hline Sub-base layer (cm) & 38.1 & 49.53 & 15.24 & 30.48 \\
\hline Pavement cost $(\$)$ & 260,082 & 263,182 & 302,414 & 276,160 \\
\hline
\end{tabular}


Table 13 Structural numbers of designed and actual upgraded pavements

\begin{tabular}{|c|c|c|c|c|c|c|c|c|}
\hline \multirow[t]{2}{*}{ County } & \multirow{2}{*}{$\begin{array}{c}\text { Capacity } \\
\text { (MLY) }\end{array}$} & \multicolumn{3}{|c|}{ Actual as-built pavement layer thickness $(\mathrm{cm})$} & \multirow{2}{*}{$\begin{array}{c}\text { As-built structural } \\
\text { number }\end{array}$} & \multicolumn{3}{|c|}{ Proposed structural number } \\
\hline & & Surface & Binder & Base & & $\begin{array}{l}5 \text {-year design } \\
\text { period }\end{array}$ & $\begin{array}{c}10 \text {-year design } \\
\text { period }\end{array}$ & $\begin{array}{c}20-\text { year design } \\
\text { period }\end{array}$ \\
\hline Jay & 246 & 5.08 & 5.08 & $15.24 \mathrm{~min}$ & 1.8 & 2.8 & 3.1 & 3.4 \\
\hline Posey & 333 & 7.62 & 5.08 & 15.24 & 2.2 & 2.9 & 3.2 & 3.6 \\
\hline Wabash & 246 & 10.16 & 10.16 & 17.78 stabilized & 3.8 & 3.1 & 3.4 & 3.8 \\
\hline
\end{tabular}

counties used developer and local suggestions. The results of the worksheet are closest to the engineering firm's recommendations. With all inputs (except the plant capacity and the design period) being set at default values, this suggests that a proper design may be consistent with the worksheet's default output. If more information was available, such as the soil CBR or the design period, the results would likely be more accurate.

Turning to the wind farm spreadsheet validation, it is noteworthy that in 2008, several lease agreements were signed with local farmers and land owners in White County, with the intention of building electricitygenerating wind towers. A private consultant was hired to insure that the adjacent roads would be capable of handling the transportation of the wind tower components. The engineering firms performed an extensive field evaluation which included soil borings from all adjacent pavement sections, lab testing and soil classification of the collected soil samples, and performing non-destructive pavement testing using a falling weight deflectometer (FWD). Note that pavement surface deflection is typically used to evaluate the flexible pavement structure and the rigid pavement load transfer and is measured as the pavement surface's vertical deflected distance as a result of an applied static or dynamic load [79-82]. The FWD is the most common type of equipment to measure the surface deflection in Indiana, and the units used are thousandths of centimeters from a FWD center-of-load deflection, corrected to a 11,340-kg load applied on a 30-cm-diameter plate, adjusted for temperature $\left(18^{\circ} \mathrm{C}\right)[83,84]$.

The engineering firms along with the White County highway department concluded that pavement upgrades were required. The engineering firm assumed the construction of 127 wind towers (phase I of the project) which included 5,000 concrete trucks, 8,000 gravel haul trucks, 1,150 semi-trucks for turbine component delivery, and numerous passes by medium and heavy cranes. This resulted in a total of 14,150 vehicles (plus crane passes). This value is more conservative than the 11,557 vehicles assumed by the wind farm worksheet. Even though the worksheet underestimates the number of trucks, it is important to note that the design methodology is based on the maximum truck weight for any truck category that constitutes more than $10 \%$ of the truck traffic. The consulting firm and the worksheets both used 4,536 kg per tire as their maximum weight.

The engineering consulting firm developed a pavement design that included the pavement layer thicknesses to carry the wind turbine components and construction materials. The SN was attained by the consultant using the AASHTO design guide for low-volume aggregate surfaced roads [56] and considered allowable rutting. Table 14 lists the consultant and worksheet results.

As expected, the worksheet provides a higher SN than the one proposed by the consultant. This could be due to the fact that the consultant has more accurate information on this specific project due to the tests that were performed, or it could be due to the selection of design procedure. It can be argued that a low-volume road design is also applicable because the number of ESAL is expected to be small. However, the developed worksheet uses the heavy wheel design, which more closely matches the given traffic scenario (the heavy construction loads).

\section{Conclusions}

Data associated with sustainable energy facility traffic (such as number, type, and weight of trucks with or without cargo) were collected, to develop Excel-based

Table 14 Wind farm worksheet and county consultant inputs and results

\begin{tabular}{lcc}
\hline Input criteria & $\begin{array}{c}\text { Consultant } \\
\text { design }\end{array}$ & $\begin{array}{c}\text { Worksheet } \\
\text { design }\end{array}$ \\
\hline Number of turbines & 127 & 127 \\
Truck traffic assumed & 14,150 & 11,557 \\
California bearing ratio & 3 & 3 \\
Soil resilient modulus (Mpa) & 41.37 & 35.58 \\
Allowable rutting (cm) & 5 to 7.5 & N/A \\
Allowable loss of service & 3 & N/A \\
Aggregate base modulus (Mpa) & 206.4 & N/A \\
Percent heavy trucks (\%) & 80 & 4,536 \\
Maximum load per tire (kg) & 4,536 & 1.9 \\
Recommended structural number & 1.3 & - \\
Recommended pavement layer thickness & - & 5.08 \\
Hot mix asphalt surface (cm) & 0 & 30.5 \\
Stabilized aggregate base (cm) & 30.5 & \\
\hline
\end{tabular}


tools (worksheets) and assist local agencies in the design of pavements in the proximity of ethanol plants, biomass plants, and wind farms. The worksheets provide a user-friendly environment for engineers with any level of expertise to produce a pavement design for the aforementioned facilities in an easy and timely fashion. Experienced designers have the option to change the default values of the worksheets in order to produce more cost-effective designs. Otherwise, the worksheets' default values can be maintained and still provide a conservative design.

From the comparison of the worksheet-generated designs and those practically implemented, it was found that the worksheet-proposed pavements were slightly thicker than the actual implemented designs, and thus less likely for the pavement to fail. This could reflect a need for collection of additional data points, or for further calibration of the tool through additional validation tasks. To that end, the as-built pavement sections will be revisited after 1- to 5-year intervals to assess their condition and further validate the worksheet tools.

The developed worksheets can serve as a hands-on tool to assist local government engineers in evaluating and quantifying the probable effects of the construction and operation of a sustainable energy facility in their jurisdiction. Further recommendations to assist in achieving this goal involve inclusion of biodiesel plants, further validation of the worksheets using measures of pavement distress (rutting or cracking), and comparison of the design outputs with actual data from constructed roads.

\footnotetext{
Abbreviations

AASHTO: American Association of State Highway and Transportation Officials; Al: Asphalt Institute; W/KWh: watts per kilowatt-hour; CBR: California bearing ratio; DDG: dried distillers grains; DDGS: dried distillers grains with solubles; ESAL: equivalent single axle loads; FFV: flexible fuel vehicles; FWD: falling weight deflectometer; LEF: load equivalency factor; MEPDG: MechanisticEmpirical Pavement Design Guide; MLY: millions of liters per year; MR: resilient modulus; MWe: megawatts electrical; PCA: Portland Cement Association; $P_{\mathrm{o}}$ : initial pavement serviceability; $P_{\mathrm{t}}$ : terminal serviceability index;
} $R \%$ : reliability; SN: structural number; TIF: tax increment financing.

\section{Competing interests}

The authors declare that they have no competing interests.

\section{Authors' contributions}

KAW and WR collected the data and conducted the analysis. PA and KAW drafted the manuscript. JH, JF, and PA led and coordinated the study and affected its design. All authors read and approved the final manuscript.

\section{Acknowledgements \\ The authors would like to thank Neal Carboneau and John Habermann for their useful comments. The contents of this paper reflect the views of the authors who are responsible for the facts and the accuracy of the information presented herein and do not necessarily reflect the official views or policies of the FHWA and INDOT nor do they constitute a standard, specification, or regulation.}

\section{Author details}

${ }^{1}$ School of Civil Engineering, Purdue University: Indiana Local Technical Assistance Program, 550 Stadium Mall Drive, West Lafayette, IN 47907, USA. ${ }^{2}$ Department of Civil, Structural and Environmental Engineering, Institute for
Sustainable Transportation and Logistics, University at Buffalo, The State University of New York, 241 Ketter Hall, Buffalo, NY 14260, USA.

${ }^{3}$ Bertsch-Frank \& Associates, LLC, 4630 W. Jefferson Blvd. \#6, Fort Wayne, Indiana 46804, USA.

Received: 16 December 2013 Accepted: 10 April 2014 Published: 26 June 2014

\section{References}

1. Bischoff A (2012) Insights to the internal sphere of influence of peasant family farms in using biogas plants as part of sustainable development in rural areas of Germany. Energ Sustain Soc 2:9

2. Dampier JE, Shahi C, Lemelin R, Luckai N (2013) From coal to wood thermoelectric energy production: a review and discussion of potential socio-economic impacts with implications for Northwestern Ontario, Canada. Energ Sustain Soc 3:11

3. Galich A, Marz L (2012) Alternative energy technologies as a cultural endeavor: a case study of hydrogen and fuel cell development in Germany. Energ Sustain Soc 2:2

4. Green JS, Geisken M (2013) Socioeconomic impacts of wind farm development: a case study of Weatherford, Oklahoma. Energ Sustain Soc 3:2

5. Grunwald A, Rösch C (2011) Sustainability assessment of energy technologies: towards an integrative framework. Energ Sustain Soc 1:3

6. Hagen Z (2012) A basic design for a multicriteria approach to efficient bioenergy production at regional level. Energ Sustain Soc 2:16

7. Halder P, Weckroth T, Mei Q, Pelkonen P (2012) Nonindustrial private forest owners' opinions to and awareness of energy wood market and forestbased bioenergy certification - results of a case study from Finnish Karelia. Energ Sustain Soc 2:19

8. Hassan MK, Halder P, Pelkonen P, Pappinen A (2013) Rural households' preferences and attitudes towards biomass fuels - results from a comprehensive field survey in Bangladesh. Energ Sustain Soc 3:24

9. Klagge B, Brocke T (2012) Decentralized electricity generation from renewable sources as a chance for local economic development: a qualitative study of two pioneer regions in Germany. Energ Sustain Soc 2:5

10. Mohr A, Bausch L (2013) Social sustainability in certification schemes for biofuel production: an explorative analysis against the background of land use constraints in Brazil. Energ Sustain Soc 3:6

11. Niemetz N, Kettl K-H (2012) Ecological and economic evaluation of biogas from intercrops. Energ Sustain Soc 2:18

12. Nishimura K (2012) Grassroots action for renewable energy: how did Ontario succeed in the implementation of a feed-in tariff system? Energ Sustain Soc 2:6

13. Oyedepo SO (2012) Energy and sustainable development in Nigeria: the way forward. Energ Sustain Soc 2:15

14. Palmas C, Abis E, von Haaren C, Lovett A (2012) Renewables in residential development: an integrated GIS-based multicriteria approach for decentralized micro-renewable energy production in new settlement development: a case study of the eastern metropolitan area of Cagliari, Sardinia, Italy. Energ Sustain Soc 2:10

15. Scheer D, Konrad W, Scheel O (2013) Public evaluation of electricity technologies and future low-carbon portfolios in Germany and the USA. Energ Sustain Soc 3:8

16. Stoeglehner G, Niemetz N, Kettl K-H (2011) Spatial dimensions of sustainable energy systems: new visions for integrated spatial and energy planning. Energ Sustain Soc 1:2

17. Taheripour F, Hertel TW, Liu J (2013) The role of irrigation in determining the global land use impacts of biofuels. Energ Sustain Soc 3:4

18. Taheripour F, Zhuang Q, Tyner WE, Lu X (2012) Biofuels, cropland expansion, and the extensive margin. Energ Sustain Soc 2:25

19. Tunç M, Pak R (2012) Impact of the clean development mechanism on wind energy investments in Turkey. Energ Sustain Soc 2:20

20. Walter K, Bosch S (2013) Intercontinental cross-linking of power supply calculating an optimal power line corridor from North Africa to Central Europe. Energ Sustain Soc 3:14

21. Dooley F, Tyner W, Sinha KC, Quear J, Cox L, Cox M (2009) The impacts of biofuels on transportation and logistics in Indiana. Technical Report SPR3133. Joint Transportation Research Program (JTRP), Indiana

22. Ginder R (2006) Potential infrastructure constraints on ethanol production in lowa. http://www.econ.iastate.edu/sites/default/files/publications/papers/ p3873-2007-07-27.pdf. Accessed 2 May 2010 
23. NADO (2007) Ethanol production impacts transportation system. National Association of Development Organizations Research Foundation Transportation Special Report 2:1-6

24. AP (2007) Road shuts ethanol plant. Associated Press. http://www. rapidcityjournal.com/news/state-and-regional/article_4edf0925-4fc1-51068d7a-12cadda26bad.html. Accessed 3 Sept 2009

25. Wakeley HL, Griffin WM, Hendrickson C, Matthews HS (2008) Alternative transportation fuels: distribution infrastructure for hydrogen and ethanol in lowa. ASCE 14:262-271

26. Kissel C, Cassady J (2008) Wind industry promises rural jobs, transportation challenges. http://66.132.139.69/uploads/nadort020608b.pdf. Accessed 2 May 2010

27. Tidemann M (2010) Turbines for ethanol plant OK'd. Estherville Daily News. http://www.esthervilledailynews.com/page/content.detail/id/501320.html. Accessed 10 April 2010

28. Tanaka AM, Anastasopoulos PC, Carboneau N, Fricker JD, Habermann JA, Haddock JE (2012) Policy considerations for construction of wind farms and biofuel plant facilities: a guide for local agencies. State Local Gov Rev 44(2):140-149

29. Reynolds RE (2000) The current fuel ethanol industry transportation, marketing, distribution, and technical considerations. CD-ROM. Accessed 3 Sept 2009

30. African Development Bank Group (2011) Updated environmental and social impact assessment summary: Lake Turkana Wind Power Project. African Development Bank Group, Kenya

31. González J, Rodríguez Á, Mora J, Burgos Payán MM, Santos J (2011) Overall design optimization of wind farms. Renewable Energy 36(7):1973-1982

32. Kinoshita T, Ohki T, Yamagata Y (2010) Woody biomass supply potential for thermal power plants in Japan. Appl Energy 87(9):2923-2927

33. Kumar A, Cameron JB, Flynn PC (2003) Biomass power cost and optimum plant size in western Canada. Biomass Bioenergy 24(6):445-464

34. Ozerdem B, Ozer S, Tosun M (2006) Feasibility study of wind farms: a case study for Izmir, Turkey. J Wind Eng Ind Aerodyn 94(10):725-743

35. Tensar (2013) Retrieved March 7, 2014, from Wind farm access roads: two decades of floating roads. http://www.tensar.co.uk/ /media/ 548441FC4F6F4B6D90EB410B2969585B.ashx. Accessed 7 March 2014

36. The British Wind Energy Association (1994) Best practice guidelines for wind energy development. The British Wind Energy Association, London

37. Van Haaren R, Fthenakis V (2011) GIS-based wind farm site selection using spatial multi-criteria analysis (SMCA): evaluating the case for New York State. Renew Sustain Energy Rev 15(7):3332-3340

38. McAloon A, Taylor F, Yee W, Ibsen K, Wooley R (2000) Determining the cost of producing ethanol from corn starch and lignocellulosic feedstocks. Technical Report NREL/TP-580-28893. US Department of Agriculture and National Renewable Energy Laboratory, Golden

39. Shurson J (2010) Distillers grain by-products in livestock and poultry feeds. http://www.ddgs.umn.edu/Genlnfo/Overview/index.htm. Accessed 10 Oct 2010

40. AFDC (2009) Data, analysis and trends. Alternative Fuels \& Advanced Vehicles Data Center. http://www.afdc.energy.gov/data/categories/vehicles. Accessed 15 Oct 2009

41. RFA (2008) Industry Statistics: US fuel ethanol demand. Renewable Fuel Association. http://www.in.gov/isda/biofuels/. Accessed 11 July 2010

42. Bruglieri M, Liberti $L$ (2008) Optimal running and planning of a biomassbased energy production process. Energy Policy 36:2430-2438

43. EIA (2007) Energy and economic impacts of implementing both a 25 percent rps and a 25 percent ifs by 2025. Energy Information Administration, US Department of Energy, Washington, DC, http://www.eia.doe.gov/oiaf/servicerpt/ eeim/issues.html. Accessed 11 July 2010

44. EIA (2009) Alternative fueling station total counts by state and fuel type. Energy Information Administration, US Department of Energy, Washington, DC, http://www.afdc.energy.gov/fuels/stations_counts.html. Accessed 11 July 2010

45. CBEA (2003) The biomass power industry in the United States. California Biomass Energy Aliance. http://www.calbiomass.org/. Accessed 11 July 2010

46. DNR (2010) Woody biomass feedstock for the bioenergy and bioproducts industries. Indiana Department of Natural Resources. http://www.extension. purdue.edu/renewable-energy/docs/IBEWG/fo-WoodyBiomass_final.pdf. Accessed 1 Feb 2011
47. RED (2009) Biomass Milltown Power Plant. Renewable Energy Development. http://renewableenergydev.com/red/biomass-milltown-power-plant/. Accessed 1 Feb 2011

48. Bastos CP (2010) Contributions of solar and wind energy to the world electrical energy demand. http://www.sefidvash.net/fbnr/pdfs/ Solar_and_Wind_Energy.pdf. Accessed 1 Feb 2011

49. Brown LR (2006) Wind energy demand booming: cost dropping below conventional sources marks key milestone in US shift to renewable energy. http://www.earth-policy.org/index.php?/plan_b_updates/2006/update52. Accessed 1 Feb 2011

50. EERE (2010) 80-meter wind maps and wind resource potential. http://www windpoweringamerica.gov/wind_maps.asp. Accessed 1 Feb 2011

51. Tchou J (2008) Wind energy in the United States: a spatial-economic analysis of wind power. http://www.gsd.harvard.edu/academic/fellowships/prizes/gisprize/ay07-08/Jeremy_Tchou.pdf. Accessed 1 Feb 2011

52. AWEA (2009) US wind energy projects - Indiana. American Wind Energy Association, Washington, DC

53. Lautal P, Stewart R, Handler R, Pouryousef H (2012) Michigan Economic Development Corporation Forestry Biofuel Statewide Collaboration Center. Task B1 Evaluation of Michigan Biomass Transportation Systems. Final Report. Michigan Tech Transportation Institute, Rain Transportation Program, p 112. http://www.michiganforestbiofuels.org/sites/default/files/Evaluation\% 20of\%20Michigan\%20Biomass\%20Transportation\%20Systems\%20-\%20FBSCC \%20Task\%20B1.pdf. Accessed 2 March 2013

54. McGregor B (2010) A reliable waterway system is important to agriculture. Technical report. Agriculture Marketing Service - US Department of Agriculture, http://www.ams.usda.gov/amsv1.0/getfile?ddocname=stelprd c5083396\&acct=atpub. Accessed 1 Feb 2011

55. Casavant K (2010) Study of rural transportation issues. Technical report, USDA and USDOT

56. Denicof MR (2007) Ethanol transportation backgrounder: expansion of US corn-based ethanol from the agricultural transportation perspective. Technical report, United States Department of Agriculture

57. AASHTO (1993) Guide for design of pavement structures. American Association of State Highway and Transportation Officials. , Washington DC

58. Asphalt Institute (Al) (1981) Thickness design—asphalt pavements for highways and streets. MS-1, Manual Series No. 1, 9th edn

59. AASHTO (2008) Mechanistic-Empirical Pavement Design Guide. Interim edition: a manual of practice. AASHTO, Washington, DC, p 212

60. Portland Cement Association (PCA) (2001) Thickness design for soil-cement pavements. Portland Cement Association 30:EB068

61. Asphalt Institute (Al) (2001) Thickness design: asphalt pavements for heavy wheel loads. Manual Series No. 23 (MS-23), 2nd edn. Asphalt Institute, Lexington

62. Anastasopoulos PC (2007) Performance-based contracting for roadway maintenance operations. Thesis, Purdue University, West Lafayette, Indiana, M.Sc

63. Anastasopoulos PC, Labi S, McCullouch BG (2009) Analyzing duration and prolongation of performance-based contracts using hazard-based duration and zero-inflated random parameters Poisson models. Transp Res Rec 2136:11-19

64. Anastasopoulos PC, McCullouch BG, Gkritza K, Mannering FL, Sinha KC (2010) Cost savings analysis of performance-based contracts for highway maintenance operations. ASCE Journal of Infrastructure Systems 16(4):251-263

65. Anastasopoulos PC, Florax RJGM, Labi S, Karlaftis MG (2010) Contracting in highway maintenance and rehabilitation: are spatial effects important? Transp Res Part A: Policy Pract 44:136-146

66. Anastasopoulos PC, Labi S, McCullouch BG, Karlaftis MG, Moavenzadeh F (2010) Influence of highway project characteristics on contract type selection: empirical assessment. ASCE Journal of Infrastructure Systems 16(4):323-333

67. Anastasopoulos PC, Islam M, Volovski M, Powell J, Labi S (2011) Comparative evaluation of public-private partnerships in roadway preservation. Transp Res Rec 2235:9-19

68. Anastasopoulos PC, Volovski M, Labi S (2013) Preservation: are 'public private partnerships' cutting costs? Pavement Preservation J 6(3):33-35

69. Anastasopoulos PC, Haddock JE, Peeta S (2013) Improving system wide sustainability in pavement preservation programming. J Transp Eng-ASCE 140(3):04013012

70. Wiltsee G, Wiltsee $\mathrm{G}$ (2000) Lessons learned from existing biomass power plants. Technical Report NREL/SR-570-26946. National Renewable Energy Laboratory (NREL). US Department of Energy, Washington, DC 
71. EPA (2006) National Electric Energy Data System. NEEDS. US Environmental Protect Agency. http://epa.gov/airmarkets/progsregs/epa-ipm/ BaseCase2006.html. Accessed 20 April 2010

72. GE (2004) 1.5s //1.5s Wind turbine. http://www.ewashtenaw.org/government/ departments/planning_environment/planning/wind_power/Monthly\% 20Data_Reports/Attachment_1.pdf. Accessed 7 Aug 2014

73. McKendry P (2002) Energy production from biomass. Part 1: overview of biomass. Bioresour Technol 83:37-46

74. Zuo Y, Maness P, Logan BE (2006) Electricity production from steam exploded corn stover biomass. Energy Fuels 20:1716-1721

75. Mani S, Tabil LG, Sokhansanj S (2004) Grinding performance and physical properties of wheat and barley straws, corn stover and switchgrass. Biomass Bioenergy 27:339-352

76. Armstrong J (2009) Wind farms and county roads. Interview preformed by Wayne Richardson

77. The Manitowoc Company, Inc (2009) Manitowoc 16000 product guide. Manitowoc, Wisconsin

78. The Manitowoc Company, Inc (2009) Manitowoc 999 product guide. Manitowoc, Wisconsin

79. Fricker JD, Whitford RK (2004) Fundamentals of transportation engineering: a multimodal approach. Prentice Hall, New Jersey

80. Till RD (2009) Overload truck wheel load distribution on bridge decks. Technical Report R-1529. Structural Section, Construction and Technology Division, Michigan Department of Transportation (MDOT), Lansing

81. Eamon CD, Nowak AS (2003) LRFD calibration for wood bridges. CD-ROM

82. Anastasopoulos PC (2009) Infrastructure asset management: a case study on pavement rehabilitation. Ph.D. Dissertation. Purdue University, West Lafayette, Indiana, Available electronically from http://search.proquest.com/ docview/304991168. Accessed 15 Aug 2011

83. Anastasopoulos PC, Labi S, Karlaftis MG, Mannering FL (2011) Exploratory state-level empirical assessment of pavement performance. ASCE Journal of Infrastructure Systems 17(4):200-215

84. Anastasopoulos PC, Mannering FL, Haddock JE (2012) Random parameters seemingly unrelated equations approach to the post-rehabilitation performance of pavements. ASCE Journal of Infrastructure Systems 18 (3):176-182

doi:10.1186/2192-0567-4-14

Cite this article as: AbdelWarith et al:: Design of local roadway infrastructure to service sustainable energy facilities. Energy, Sustainability and Society 2014 4:14

\section{Submit your manuscript to a SpringerOpen ${ }^{\circ}$ journal and benefit from:}

- Convenient online submission

- Rigorous peer review

- Immediate publication on acceptance

- Open access: articles freely available online

- High visibility within the field

- Retaining the copyright to your article

Submit your next manuscript at $\gg$ springeropen.com 